\begin{tabular}{l}
\multicolumn{1}{c}{ AUSTRALIAN JOURNAL OF BASIC AND } \\
APPLIED SCIENCES
\end{tabular}

\title{
Initial development of licuri (Syagrus coronata (Mart.) Becc.) -Arecaceae seedlings under different substrates and luminosity levels
}

${ }^{1}$ Michele Lima de Souza, ${ }^{1}$ Jorge Marcelo Padovani Porto, ${ }^{1}$ Viviane Lima de Oliveira, ${ }^{1}$ Rafaeli Aparecida Vieira de Souza, ${ }^{1}$ Márcia Santos Carvalho and ${ }^{1}$ Francyane Tavares Braga

${ }^{1}$ Departamento de Educação, Universidade do Estado da Bahia, 48608-240, Paulo Afonso, BA, Brazil.

\section{Address For Correspondence:}

Francyane Tavares Braga, Departamento de Educação, Universidade do Estado da Bahia, Rua da Gangorra, 503, Paulo Afonso, BA, 48608240, Brasil.

E-mail: ftbraga@yahoo.com.br; Phone: +55 75992103432

\section{ART ICLE INFO}

\section{Article history:}

Received 12 October 2017

Accepted 22 November 2017

Available online 6 December 2017

Keywords:

Brazilian Northeast, Caatinga, leaf anatomy, shading.

\begin{abstract}
A B S T RA C T
Licuri is a palm tree typical of the Brazilian Northeast semi-arid region and of great socioeconomic importance for communities in the region. Despite its importance, few works were developed addressing its propagation and conservation. Studies about luminosity levels and different substrates may result in different growth responses, optimizing the production of seedlings. Therefore, the aim of this study was to evaluate the initial growth and compare the leaf anatomy of licuri seedlings subjected to different substrates and light levels. Licuri seedlings were conditioned in full sun and $50 \%$ shading, and the substrates sand, vegetal soil, sand mixed with organic compound and vegetal soil mixed with organic compound. After 90 days of cultivation, was evaluating growth and foliar anatomy. The shoot height, total leaf area, number of leaves, leaf dry weight, stem dry weight and root dry weight showed higher values in the seedlings grown in 50\% shading. In full sun, there was an increase only for stem diameter. The dry weight of the root was significantly greater in sand or vegetal soil. For the total leaf area, the same substrates, however, with the presence of the organic compound, presented higher values. Seedlings grown under full sun provided greater thicknesses of adaxial epidermis and adaxial hypodermis. The abaxial epidermis, abaxial hypodermis and mesophyll presented greater thicknesses, regardless of the luminosity tested, in the substrates that contained vegetal soil, with or without the presence of organic compound. The use of sand or vegetable soil and the shaded environment provide better conditions for the production of licuri seedlings. Foliar anatomical analysis is a good indicator to verify the quality of licuri seedlings when grown under different environmental conditions.
\end{abstract}

\section{INTRODUCTION}

Plant species of the Arecaceae family are represented in almost all the territory of the Caatinga and present big environmental and socioeconomic importance for the regional. Among the species, its stands out the Syagrus coronata (Mart.) Becc.), one of the most important palm trees of the Brazilian semi-arid region (Drumond, 2007). Known as licuri, this palm tree presents great socioeconomic importance in its area of occurrence, using all the structural components of its aerial part. Its leaves, sheaths, seeds and fruits are used in the making of handicrafts, utensils, animal food and cooking (Drumond, 2007). The characterization of its oil brings the perspective of the use in the cosmetic and pharmaceutical industry, as anti-inflammatory (Bauer, 2013).

Despite its importance, licuri is subjected to intense irrational exploitation and enormous depredation, justifying, in this way, basic studies of propagation and creation of management strategies for this species

Open Access Journal

Published BY AENSI Publication

(C) 2017 AENSI Publisher All rights reserved

This work is licensed under the Creative Commons Attribution International License (CC BY).

http://creativecommons.org/licenses/by/4.0/

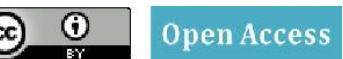

To Cite This Article: Michele Lima de Souza, Jorge Marcelo Padovani Porto, Viviane Lima de Oliveira, Rafaeli Aparecida Vieira de Souza, Márcia Santos Carvalho and Francyane Tavares Braga, Initial development of licuri (Syagrus coronata (Mart.) Becc.) - Arecaceae seedlings under different substrates and luminosity levels. Aust. J. Basic \& Appl. Sci., 11(14): 103-109, 2017 
(Crepaldi, 2001). Among these studies, to evaluate the light levels and substrates for the better development of seedlings it is fundamental.

In general, the substrate used for seedling formation may favor or hinder the growth of seedlings. Due to the different components that have been used for a substrate formulation, there is a need to determine the best possible for the development of each species, aiming at providing nutrients and with adequate physical properties, such as water retention, aeration and ease of penetration roots, among others (Guimarães et al., 2006).

Another factor that has a significant influence on the growth of seedlings is the luminosity. The efficiency of leaves for light interception, the ability to convert this energy into carbohydrates, as well as its transport and metabolism in the different parts within the tree are factors that influence the growth and survival of palm trees developing in adversity (Scariot, 2001). For exemplo, young plants of Euterpe edulis Martius (Arecaceae) showed greater survival index in environment with greater light availability, than in shaded environment (Ribeiro et al., 2011), as well as Copernicia prunifera (Miller) H. E. Moore (Arecaceae) that developed better when growing at full sunlight when compared to plants growing under 50\% of shading (Reis et al., 2011). Few studies were performed with licuri if compared to other crops, especially regarding the problems and requirements associated with the production of plants in the initial stages. In practice, it has been observed significant losses in the growth due to several factors, such as the level of light incidence (Carvalho et al., 2006).

To better verify the changes in plants grown under different light conditions and substrate types, anatomical studies contribute to the knowledge and understanding of physiological aspects, such as processes resulting from photosynthesis, observing, from the leaf structure, the production, transport and storage of photoassimilates (Tomlinson, 1990).

Therefore, the aim of this study was to evaluate the initial growth and compare the leaf anatomy of licuri seedlings subjected to different substrates and light levels.

\section{MATERIALS AND METHODS}

The fruits were collected in an area of 1.2 hectares located in the town of Juá, in the municipality of Paulo Afonso-BA (09 $26^{\prime} 48.8$ "S and 38 $25^{\prime} 53.1^{\prime \prime} \mathrm{W}$ and altitude of 428 meters), inserted in the ecoregion of Raso da Catarina. After the collection, they were taken to the laboratory, immersed in water for 24 hours and benefited by manual removal of the pulp (pericarp). They were then allowed to dry at room temperature in the shade for 48 hours for further use in the experiments.

With the aid of a sandpaper ( $\left.n^{\circ} 80\right)$, the seeds were partially scarified on the region to the micropyle. Subsequently, they were disinfested with immersion in $70 \%$ alcohol for 30 seconds and $1 \%$ sodium hypochlorite for10 minutes, and washed in distilled water. After disinfestation, the seeds were pre-soaked in distilled water for 24 hours and sown in trays containing washed sand. The seeds were kept in a germination chamber, in the dark and at a constant temperature of $25^{\circ} \mathrm{C}$.

For the production of the organic compound used in the treatments, were used alternating layers of coffee grounds, cattle manure and shredded straw of Crotalaria sp. The irrigation was carried out according to the need, based on weekly monitoring of humidity, performed visually. The turnover was performed three times during the curing process, which was terminated after approximately 100 days. Analysis of the material revealed: $\mathrm{pH}=7.4 ; \mathrm{N}=9.2 \mathrm{~g} \mathrm{~kg}^{-1} ; \mathrm{P}=4.7 \mathrm{~g} \mathrm{~kg}^{-1} ; \mathrm{K}=8.4 \mathrm{~g} \mathrm{~kg}^{-1} ; \mathrm{Ca}=8.1 \mathrm{~g} \mathrm{~kg}^{-1} ; \mathrm{Mg}=6.6 \mathrm{~g} \mathrm{~kg}^{-1}$.

Three-month-old seedlings were selected and transplanted into black polyethylene bags $(20 \times 28 \mathrm{~cm})$ drilled in the base, containing the substrates: vegetal soil; vegetal soil + organic compound (3:1); sand and; sand + organic compound (3:1), using $300 \mathrm{mg}-1$ substrate per treatment. Afterwards, the seedlings were conditioned under full sun and 50\% shading, obtained with the use of shading screens. A daily water regime was adopted, always maintaining the field capacity of the substrate in $60 \%$.

After 90 days, the following growth characteristics were evaluated: shoot height; stem diameter; number of leaves; total leaf area; leaf dry weight; stem dry weight and; root dry weight. Subsequently, calculated total dry weight and shoot/root dry weight ratio. For the number of leaves, the fully expanded leaves were selected. For the stem diameter, the posterior region to the surface of the substrate and, the shoot height, the distance between the surface of the substrate and the apex of the longer leaf was measured. For the dry weight, the seedlings were washed in running water to remove excess substrate, sectioned at the height of the stem, and separating the organs to be weighed. After this process, all the material was taken to the forced circulation oven at temperature of $65^{\circ} \mathrm{C}$, until constant weight. The shoot/root ratio was defined as the dry weight of shoot divided by the dry weight of root. To measure the total leaf area, the leaves were scanned and measurements were taken with ImageToo® software.

For the anatomy, five samples were collected per treatment. For this, completely expanded adult leaves were chosen. After the collection, the material was quickly fixed in $70 \%$ alcohol, where they remained stored until the procedure of the anatomical cuts. 
The cross-sections of the leaves were performed according to the methodology described by Kraus and Arduim (1997). The blades were photographed using a camera attached to the optical microscope. The thicknesses of the epidermis, hypodermis, and mesophyll were measurements using ImageToo® software.

The experimental design was completely randomized in a $4 \times 2$ factorial scheme, with four substrates and two lighting environments. Five plants were used per replicate and five replicates per treatment, making a total of 25 seedlings per treatment. The results were submitted to analysis of variance and the means were compared by Tukey's test at 5\% of probability, using statistical software Sisvar 5.3 (Ferreira, 2011).

\section{RESULTS AND DISCUSSION}

Analysis of variance showed no interaction between the factors tested. Both shoot height (Fig. 1A) and stem dry weight (Fig. 1G) present higher values for the seedlings grown in 50\% shading. In work conducted with seedlings of Schizolobium amazonicum Huber ex Ducke, Matos et al. (2009) verified that 75\% of shading favored shoot growth. According to Veglio (2010), the restriction of the radiation induces the etiolation of the plant, being, this mechanism, caused by the interaction of phytormons. According to Franco et al. (2007), regardless of plant tolerance, height increase, either at the beginning or at later stages of development, would be a favorable response to the survival of the plant under shading condition, due to positive net growth considered as a factor of greater importance (Lusk, 2004).

A

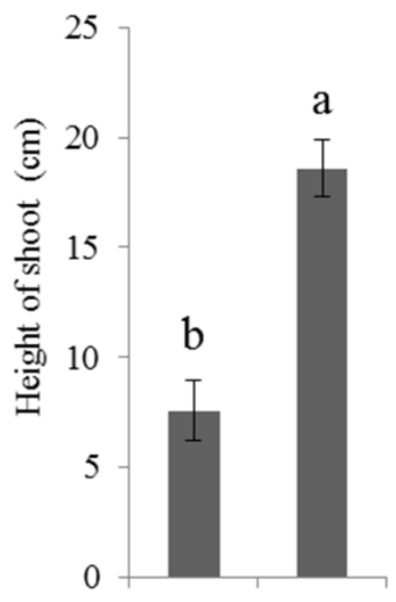

$\mathrm{D}$

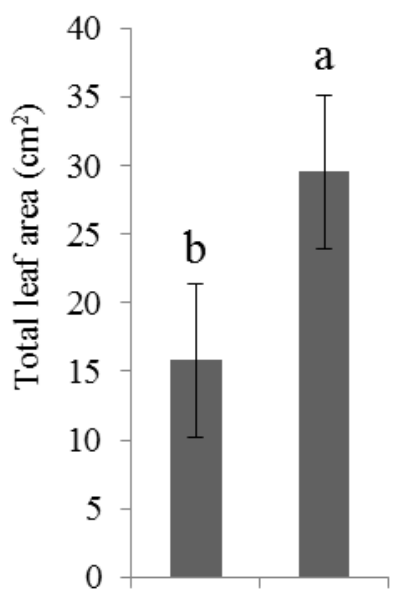

B

$\mathrm{C}$

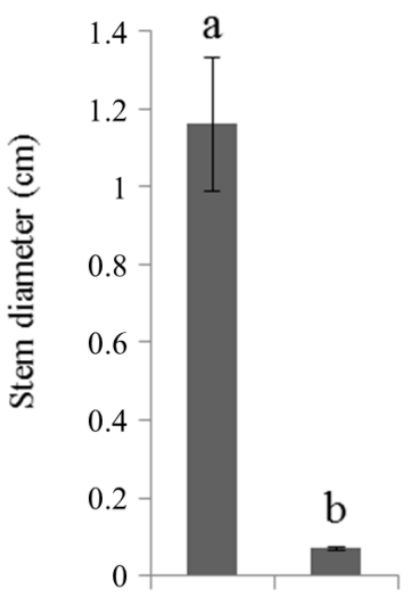

E

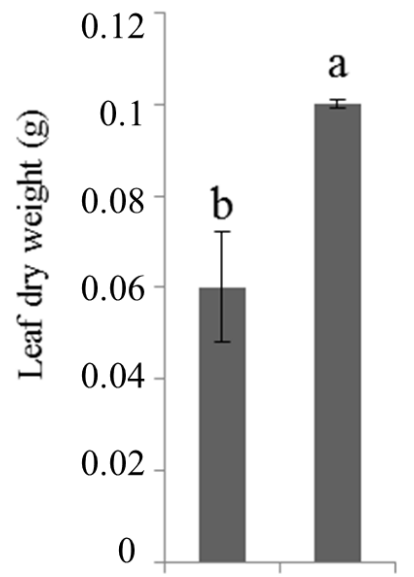

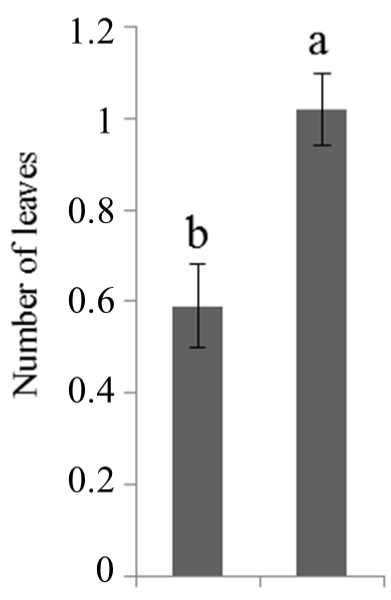

F

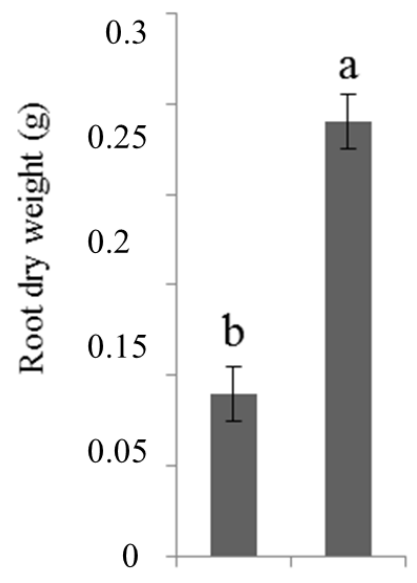



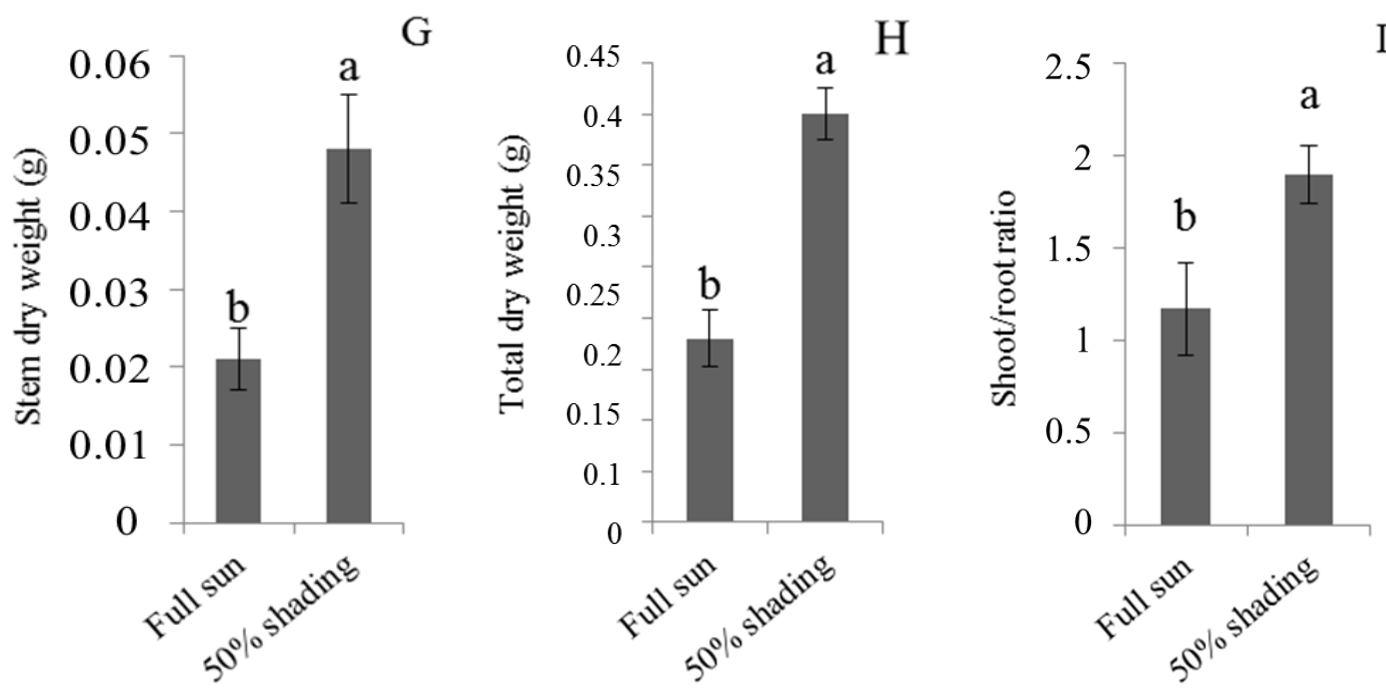

Fig. 1: Height of shoot (A), stem diameter (B), number of leaves (C), total leaf area (D), leaf dry weight (E), root dry weight $(\mathrm{F})$, stem dry weight $(\mathrm{G})$, total dry weight $(\mathrm{H})$ and shoot/root ratio $(\mathrm{I})$ of licuri seedlings submitted to different luminosity levels.

The results found for stem diameter (Fig. 1B) were inversely proportional to those presented for height. The greatest growth of the seedlings in diameter was observed in the full sun, being approximately eleven times greater than those submitted to shading. Kozlowski (1962) reported that the elevation of shading decreases photosynthesis, and consequently, the amount of photoassimilates and phytormons, causing a reduction in stem diameter of the seedlings. For the author, photosynthesis presents a more direct relation with the growth in diameter than with the growth in height.

The growth parameters obtained in this work corroborate with the results found by Carvalho et al. (2006), but diverge of the root dry weigh. The authors observed greater gain in seedlings grown in full sun, while in this experiment, the greatest values occurred under shading (Fig. 1F).Consequently, the shoot/root ratio also was different, for the authors also observed lower ratio in seedlings grown in full sun, whereas in this experiment the ratio was larger (Fig. 1I).

Regarding the number of leaves, total leaf area and leaf dry weight (Fig. 1CDE), the seedlings grown in the shade present a larger increase in relation to full sun. The increase of the leaf area in plants submitted to shading is a strategy to increase its photosynthesizing surface, ensuring greater use of low light intensities (Larcher, 2006).

The seedlings exposed to full sun presented a reduction of their total dry weight when compared to those grown under $50 \%$ shading (Fig. 1H). According to Kitao (2000), high levels of solar radiation can cause photoinhibition-like damage to the photosynthetic apparatus in plant leaves, significantly reducing photosynthesis.

Faria et al. (2002) evaluated the behavior of several genotypes of coconut trees and concluded that, regardless of the genotype, shading conditions resulted in the formation of more vigorous seedling. Analyzing the early growth of Euterpe edulis in different light regimes, Nakazono et al. (2001) described that plants developed in 20,30,50, and 70\% of light had similar development to dry matter, leaf area, and distribution of biomass between the root and aerial part, but differed from those grown in full sunlight, which showed less dry matter than shaded plants, agreeing with the results of the present study

The root dry weight and total leaf area did not show significant differences for the substrates. The root dry weight increased in seedlings growth in the sand or vegetal soil compared to the seedlings grown on the substrates containing the same compositions, however, with organic compound mixed (Fig. 2A). This largest root biomass may be related to the lower concentration of organic matter in the substrate. The investment in the root system is an interesting feature of species adapted to the semi-arid conditions, since the availability of nutrients in soils of this region is a critical factor. 

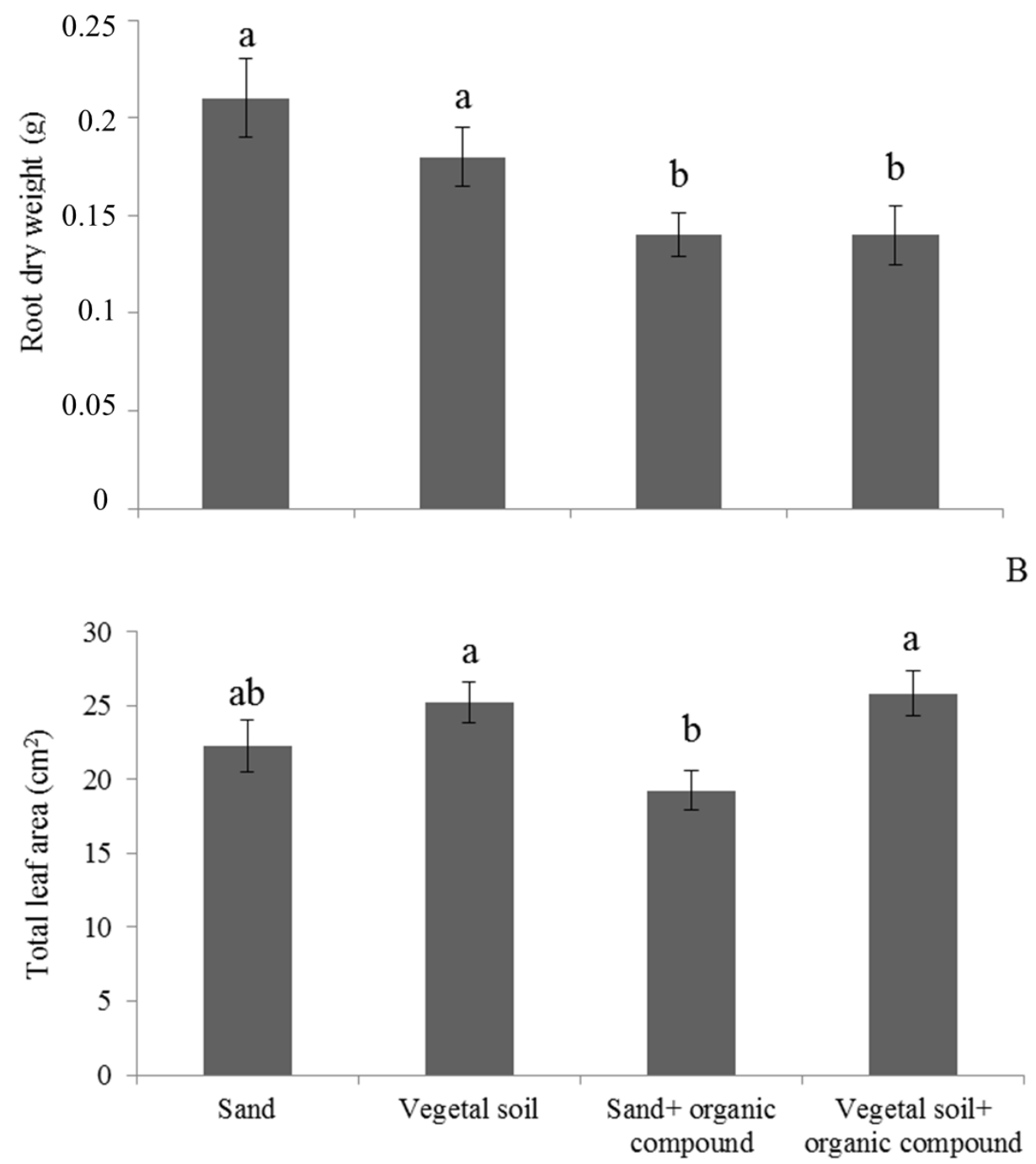

Fig. 2:Root dry weight (A) and total leaf area (B) of licuri seedlings submitted to different substrates.

As for the total leaf area, seedlings presented higher averages when grown on substrates containing vegetal soil, both in the presence or absence of the organic compound and, too, in sand (Fig. 2B). The lowest value for total leaf area, found in the treatment containing the mixture of sand and organic compound, may have been influenced by the low water retention capacity of this substrate, knowing that, as a consequence of the low water availability, one of the strategies to avoid water loss by the plant is the reduction of leaf area (Larcher, 2006).

There was interaction between the substrates and luminosity levels for thickening of adaxial hypodermis and adaxial epidermis (Table 1). The seedlings grown in the sand or sand with organic compost, under the shade, had the lowest thicknesses in relation to the other substrates. However, the seedlings cultivated in the vegetal soil substrate under full sun presented a greater thickness of adaxial epidermis. It was also observed that when adding the organic compound to the substrates, there was a reduction in thickness in the adaxial epidermis, in relation to the other substrates in full sun. In seedlings cultivated at $50 \%$ shading, for the different substrates, no differences were verified for the thickness of the adaxial epidermis, but when comparing the luminosity levels, the leaves presented greater thicknesses in substrates containing vegetal soil and sand, in full sun condition. 
Australian Journal of Basic and Applied Sciences, 11(14) December 2017, Pages: 103-109

Table 1:Leaf thickness of licuri seedlings cultivated in full sun and 50\% shading on different substrates.

\begin{tabular}{|c|c|c|c|c|}
\hline \multirow[b]{2}{*}{ Substrates } & \multicolumn{2}{|l|}{$\operatorname{Adh}(\mu \mathrm{m})$} & \multicolumn{2}{|c|}{ Ade $(\mu \mathrm{m})$} \\
\hline & Full sun & $50 \%$ shading & Full sun & $50 \%$ shading \\
\hline VS & $22.88 \mathrm{Aa}$ & $21.04 \mathrm{Aa}$ & $12.4 \mathrm{Aa}$ & $9.99 \mathrm{Ba}$ \\
\hline $\mathrm{VS}+\mathrm{OC}$ & $18.99 \mathrm{Aa}$ & $19.66 \mathrm{Aa}$ & $8.59 \mathrm{Ac}$ & $8.16 \mathrm{Aa}$ \\
\hline $\mathrm{S}$ & $21.29 \mathrm{Aa}$ & $15.78 \mathrm{Bb}$ & $10.18 \mathrm{Ab}$ & $7.97 \mathrm{Ba}$ \\
\hline $\mathrm{S}+\mathrm{OC}$ & $20.24 \mathrm{Aa}$ & $13.27 \mathrm{Bb}$ & $7.07 \mathrm{Ac}$ & $8.48 \mathrm{Aa}$ \\
\hline $\mathrm{CV}(\%)$ & 23.63 & & 23.28 & \\
\hline
\end{tabular}

Means followed by the same capital letter in the rows or small letter in the columns do not differ statistically at $5 \%$ probability, by Tukey's test. Treatments: VS, vegetal soil; VS+OC, vegetal soil and organic compound; S, sand; S+OC, sand and organic compound. Adh, adaxial hypodermis; Ade, adaxial epidermis.

In general, leaves kept under shading showed a reduction in leaf thickness when compared to those in full sun. This decrease may have been caused by the difference in the distribution of photoassimilates. At lower luminous intensity, the plants present thinner leaves due to the consumption of assimilated ones for the expansion of the leaf area (Brant, 2011). However, in plants under full sunlight, the growth of the cells in the elongation phase is reduced, and the expanding growth of the cell walls paralyzes early, tending to become thicker (Lima Júnior et al., 2006).

For the other variables, only the substrate factor was significant. The leaves presented greater thickness in plants grown in vegetal soil or vegetal soil mixed with organic compound. For abaxial hypodermis, only the vegetal soil substrate differentiated from the other treatments, presenting a greater thickness (Table 2).

Table 2: Leaf thickness of licuri seedlings cultivated in full sun and 50\% shading on different substrates.

\begin{tabular}{lccc} 
Substrates & Abe $(\mu \mathrm{m})$ & Abh $(\mu \mathrm{m})$ & Mesophyll $(\mu \mathrm{m})$ \\
\hline VS & $9.95 \mathrm{a}$ & $22.52 \mathrm{a}$ & $99.63 \mathrm{a}$ \\
VS+OC & $8.8 \mathrm{a}$ & $18.86 \mathrm{~b}$ & $80.42 \mathrm{a}$ \\
$\mathrm{S}$ & $7.74 \mathrm{~b}$ & $17.91 \mathrm{~b}$ & $71.22 \mathrm{~b}$ \\
S+OC & $7.64 \mathrm{~b}$ & $17.23 \mathrm{~b}$ & $71.86 \mathrm{~b}$ \\
\hline $\mathrm{CV}(\%)$ & 29.69 & 20.8 & 15.33 \\
\hline
\end{tabular}

Means followed by the same capital letter in the rows or small letter in the columns do not differ statistically at $5 \%$ probability, by Tukey's test. Treatments: VS, vegetal soil; VS+OC, vegetal soil and organic compound; S, sand; S+OC, sand and organic compound. Abe, adaxial epidermis; Abh, adaxial hypodermis.

As for mesophyll cells, seedlings grown in vegetal soil or vegetal soil mixed with organic compound showed higher thicknesses (Table 2). According to Braga et al. (2011), increase of mesophyll thickness is plant response to environmental conditions and demonstrates plasticity of adaptation. According to Costa et al. (2003), the microporosity of the substrate can reduce gas exchange and water infiltration, and provide water and aeration to the root system, when there is macroporosity in the substrate, thus altering, the characteristics of the mesophyll.

\section{Conclusion:}

The shaded environment is the best condition for the production of licuri seedlings.

The use of sand or vegetal soil as substrate for the licuri cultivation determines higher quality seedling, however, the vegetal soil affect less the seedlings leaf thickness.

Foliar anatomical analysis is a good indicator to verify the quality of licuri seedlings when grown under different environmental conditions.

Seedlings produced under these conditions may enhance their survival when they are transferred to field conditions, but further studies should be carried out.

\section{ACKNOWLEDGEMENT}

To Fundação de Amparo à Pesquisa do Estado da Bahia (FAPESB) and Conselho Nacional de Desenvolvimento Científico e Tecnológico (CNPq), for the financial support. 


\section{REFERENCES}

Bauer, L.C., J.M. Damásio, A.M.V. Silva, D.A. Santana, S.A. Gualberto and J.I. Simionato, 2013. Chemical characterization of pressed and refined licuri (Syagrus coronata) oils. Acta Scientiarum Technology, 35(4): 771-776.

Braga, F.T., M. Pasqual, E.M. Castroand G.C. Rafael, 2011. Características morfofisiológicas de abacaxizeiro 'gomo de mel' enraizado in vitro sob luz natural e substrato vermiculita. Revista Brasileira de Fruticultura, 33(2): 551-557.

Brant, R.S., J.E.B.P. Pinto, L.F. Rosal, C. Alves, C. Oliveira and C.J.B. Albuquerque, 2011. Adaptações fisiológicas e anatômicas de Melissa officinalis L. (Lamiaceae) cultivadas sob malhas termorrefletoras em diferentes intensidades luminosas. Revista Brasileira de Plantas Medicinais, 13(4): 467-474.

Carvalho, N.O.S., C.R. Pelacani, M.O.S. Rodrigues and I.C. Crepaldi, 2006. Crescimento inicial de plantas de licuri (Syagrus coronata (Mart.) Becc.) em diferentes níveis de luminosidade. Revista Árvore, 30(3): 351357.

Costa, C., D. Frigon, P. Dutilleul, L.M. Dwyer, V.D. Pillar, D.W. Stewart and D.L. Smith, 2003. Sample size determination for chlorophyll meter readings on maize hybrids with a broad range of canopy types. Journal of PlantNutrition, 26(5): 1117-1130.

Crepaldi, I.C., 2001. Syagrus coronata e Syagrus vagans: Palmeiras economicamente importantes da caatinga baiana. 175 p. Tese, Universidade de São Paulo, SP.

Drumond, M.A., 2007. Licuri Syagrus coronata (Mart.) Becc. Embrapa Semi-Arido, Petrolina, PE, Brasil.

Faria, W.S., H.N. Gaiva and W.E. Pereira, 2002. Pereira, Comportamento de cinco genótipos de coqueiro (Cocos nucifera L.) na fase de germinação e de crescimento de mudas, sob diferentes sistemas de produção. Revista Brasileira de Fruticultura, 24(2): 458-462.

Ferreira, D.F., 2011. Sisvar: a computer statistical analysis system. Ciência e Agrotecnologia, 35(6): 10391042

Franco, A.M.S. and L.R. Dillenburg, 2007. Ajustes morfológicos e fisiológicos em plantas jovens de Araucaria angustifolia (Bertol.) Kuntze em resposta ao sombreamento. Hoehnea, 34(2): 135-144.

Guimarães, M.M.B., L.S. Severino, N. E.M. Beltrão, F.X. Costa, J.F. Xavier and A.M.A. Lucena, 2006. Produção de muda de mamoneira em substrato contendo diferentes resíduos orgânicos e fertilizante mineral. In: Anais do Congresso Brasileiro de Mamona, 2. Aracajú: EMBRAPA.

Kitao, M., 2000. Susceptibility to photoinhibition of three deciduous broadleaf tree species with different successional traits raised under various light regimes. Plant, Cell and Environment, 23(1): 81-89.

Kozlowski, T.T., 1962.Tree growth. The Ronald Press, New York, USA.

Kraus, J.E. and M. Arduim, 1997. Manual básico de métodos em morfologia vegetal. EDUR Seropédica, Rio de Janeiro, Brasil.

Larcher, W., 2006. Ecofisiologia vegetal. Rima, São Carlos, SP, Brasil.

Lima Júnior, E.C., A.A. de Alvarenga, E.M. de Castro, C.V. Carlos Vieira and J.P.R.A.D. Barbosa, 2006. Aspectos fisioanatômicos de plantas jovens de Cupania vernalis Camb. submetidas a diferentes níveis de sombreamento. Revista Árvore, 30(1): 33-41.

Lusk, C., 2004. Leaf area and growth of juvenile temperate evergreens in low light: species of contrasting shade tolerance change rank during ontogeny. Functional Ecology, 18(6): 820-828.

Matos, G.D., T. Frigotto, A.P.M. Martins and E.J. Brun, 2009. Desenvolvimento de mudas de paricá (Schizolobium amazonicum Huber ex Ducke) em substrato orgânico: estudo de caso. Synergismus scyentifica, 4(1): 1-3.

Nakazono, E.M., M.C. Costa, K. Futatsug, M.T.S. Paulilo, 2001. Crescimento inicial de Euterpe edulis Mart. em diferentes regimes de luz. Revista Brasileira de Botânica, 24(2): 173-179.

Reis, R.G.E., M.S. Pereira, N.R. Gonçalves, D.S. Pereira and A.M.E. Bezerra, 2011. Emergência e qualidade de mudas de Copernicia prunifera em função da embebição das sementes e sombreamento. Revista Caatinga, 24(4): 43-49.

Ribeiro, T.M., S.V. Martins, V.M. Lana and K.A. Silva, 2011. Sobrevivência e crescimento inicial de plântulas de Euterpe edulis Mart. transplantadas para clareiras e sub-bosque em uma Floresta Estacional Semidecidual, em Viçosa, MG. Revista Árvore, 35(6): 1219-1226.

Scariot, A., 2001. Weedy and secondary palm species in Central Amazonian forest fragments. Acta Botânica Brasílica, 15(2): 271-280.

Tomlinson, P.B.,1990. The structural biology of palms. $1^{\text {nd }}$ Ed., Oxford University Press, New York, USA

Veglio, A., 2010. The shade avoidance syndrome: a non-Markovian stochastic growth model. Journal of Theoretical Biology, 264(3): 722-728. 